Article

\title{
Post-pyrogenic dynamics of the vegetation cover of the Barskoe raised bog (Vologda Region, Russia)
}

\author{
Anzhelika A. Malashchuk¹, Dmitriy A. Philippov²*৫ \\ ${ }^{1}$ Secondary School № 23, Lyzhnyy proezd 8, Murmansk, Murmansk Region, 183032 Russia \\ ${ }^{2}$ I.D. Papanin Institute for Biology of Inland Waters, Russian Academy of Sciences, Borok 109, Nekouz District, \\ Yaroslavl' Region, 152742 Russia \\ *philippov_d@mail.ru
}

Received: 12.05 .2020

Revised: 17.11 .2020

Accepted: 27.11 .2020

Published online: 11.02.2021

DOI: $10.23859 /$ estr-200512

UDC $581.9+58.02(470.12)$

Translated by D.M. Martynova

\begin{abstract}
The study deals with the issues of restoration of peat bogs exposed to the pyrogenic factor. The work was carried out in the Barskoe raised bog, at sites unaffected and directly affected by the ground fire of 2002. A decade later, these sites differed in species composition, phytocoenosis structure, and biomass accumulation rates. Post-pyrogenic changes in the vegetation cover of the raised bog were associated with a slight decrease in species richness, loss of moisture-demanding bog species and an increase of mesophyte's and xerophyte's roles, simplification of the mire sites structure towards the loss of complexity, reduction of phytocoenotic diversity, as well as an increase in the dry biomass stocks with a 1.3-1.4-fold decrease in the photosynthetic phytomass and a 6.4-6.7-fold increase in the mortmass. The restoration rate of the mire exposed to pyrogenic transformation can be accelerated by increasing its water table and the prevention of new fires.
\end{abstract}

Keywords: peat fire, flora, Sphagnum, phytomass stocks, mortmass, mire restoration.

To cite this article. Malashchuk, A.A., Philippov, D.A., 2021. Post-pyrogenic dynamics of the vegetation cover of the Barskoe raised bog (Vologda Region, Russia). Ecosystem Transformation 4 (1), 35-52. https://doi.org/10.23859/estr-200512

\section{Introduction}

Fires are the environmental factor that preconditions the composition, structure and dynamics of phytocoenoses (Rabotnov, 1978; Wein and MacLean, 1983), including that at mires and paludified areas (Efremova and Efremov, 1994; Kuhry, 1994; Minayeva and Sirin, 2002). The consequences of each fire in a peatland may be different, from an increase in soil fertility and an improvement in growing conditions to the loss of a number of the main biospheric functions of a mire, depending on the type of fire (crown fire, creeping fire, and underground fire), the water content of the certain site (associated with the degree of its transformation), and weather conditions.
There are several issues received much attention nowadays when studying the effects of fires on the mire ecosystems:

1) searching for the causes and sources of fires, development of general issues (Korchagin, 1954; Kosov, 2012; Panov and Tsymlyakova, 2013; Vomperskiy et al., 2007);

2) study of the fire effects on the peat soils (Efremova and Efremov, 1994, 2006; Glukhova and Sirin, 2018; Sirin et al., 2019; Tsibart et al., 2016; Zaydelman and Shvarov, 2002), waters (Akhmetyeva et al., 2011; Kučerová et al., 2008), vegetation cover (Burenina, 2006; Chumakov, 2013; Grishutkin, 2012; Grummo et al., 2010; Kochubei, 2017; Kopoteva, 
1995; Kopoteva and Kuptsova, 2016; Mazing, 1960; Napreenko, 2002; Popov, 2000), invertebrates (Kolesnikov, 2017), protozoans (Kurina and Klimova, 2016), and prokaryotes (Danilova et al., 2015);

3) development of the fire safety issues, including the assessment of potential fire hazard (Khakimov and Sinyutkina, 2014; Ul'baev and Bazaeva, 2012), minimization of consequences (Sirin et al., 2011; Zhukov and Potapov, 2010), monitoring and restoration of disturbed peat bogs (Akhmetyeva et al. et al., 2014; Makarenko, 2013; Medvedeva et al., 2019; Minayeva and Sirin, 2002; Semenova, 2016; Sirin et al., 2018; Sretenskiy, 2004; Zaydelman, 2014).

In the Vologda Region (Russia), the bioecological studies of peat fires and their impact on the environment have practically not been carried out so far (Philippov, 2010), they are limited to a few small notes from different years (Denisenkov, 1980; Lebedeva, 2005; Philippov, 2007; Pyavchenko, 1955; Zaudalov, 2006).

Regard must also be paid to a number of annual cases of peat fires in the studied region and the associated problems. Table 1 summarizes the regional Department of Natural Resources' official information for the period from 2005 to 2016 (Doklad..., 2010, 2012, 2015, 2017). Every year, 37 peat fires on average (from 4 to 122) occur in the region, covering from 0.7 to 47.2 ha (in 2010, 133.5 ha). Although the areas affected by fires, compared to the Vologda Region's total area, seem relatively small, the fires affect the population health and the national economy negatively. They require high extinguishing costs, which may reach up to 15-25 million Russian roubles in the seasons with the worst fire, and the total damage may exceed dozens of millions of Russian rubles, exceeding hundreds of millions in some years.

The study aims to identify the main changes in the species composition, coenotic structure, and in the stock of aboveground biomass in the raised bog after the fire. The work was carried out as part of the preparation of the graduation thesis of A. Malashchuk, defended successfully at Vologda State University (Russia) in 2014, some results were presented as an abstract at the conference, same year (Malashchuk, 2014).

\section{Materials and methods}

The research took place in the Sukhonskaya Lowland, located at a pre-glacial tectonic depression and a lacustrine-glacial reservoir with terraces (117$145 \mathrm{~m}$ above sea level) in the basin of the upper reaches of the Sukhona River (Lyapkina, 1985). The territory is heavily paludified (up to $25 \%$ of the total area, see: Filonenko and Philippov, 2013), which is facilitated by the general flatness of the relief, low relative elevation of the area, shallow groundwater, temperate continental climate, and the proximity of large water bodies, the Lake Kubenskoe and the
Sukhona River (Abramova, 1965; Lyapkina, 1985). The raised bogs are smaller than low moors and transitional types of moors, they are located mainly in the Sukhonskaya Lowland watersheds. Most of the raised bogs of this area, especially in the vicinity of Vologda, Sokol, and Kadnikov cities and a number of large villages, were transformed as a result of forest reclamation, drainage and peat extraction (Shevelev and Komissarov, 1994).

A model object is the Barskoe raised bog (Fig. 1), which is one of two "isolated areas" of the Vakhtyuzhskoe peatland (Torfyanoi Fond..., 1955). The mire is elongated northeasternwards along the southeastern edge of the Olarevskaya ridge (a moraine formation in the marginal zone of the Upper Valdai glaciation). It serves as the source of the Voz'ma River. It belongs to pine-cottongrass-dwarf shrubsphagnum raised bogs dominated by Sphagnum magellanicum coll. According to the detailed studies carried out in 1944 and 1947 by the State Institute for Exploration of Coal and Peat Deposits of the Fuel Industry (Gipromesttop), the mire has an area of more than $10 \mathrm{~km}^{2}$, the average depth of peat deposits is $3.36 \mathrm{~m}$ (maximum, $>6.0 \mathrm{~m}$ ). Raised-bog peat deposits of medium peat and complex raised-bog peats prevail: degree of decomposition is $10-50 \%$ (avg. $29 \%$ ), ash content, $0.7-12.4 \%$ (avg. 3.6\%), moisture content, $88.8 \%$, stumpiness, $1.2 \%$ (Torfyanoi Fond..., 1955). According to our data, the mire area is $11.1 \mathrm{~km}^{2}$.

The southwestern part of the mire is located within the Vologda District's boundaries; the northeastern part belongs to the Sokol District. The southwestern extremity of the mire near the Mezhdurech'e village was drained in 1944-1948; the peat was extracted on about 10 hectares. In the second half of the $\mathrm{XX}$ century, an amelioration ditch was dug along the eastern and southeastern edges of the mire, and the forest reclamation was carried out in several forested areas (for example, near the villages of Volkovo and Konanovo). Considering the proximity of cities (15-20 km to Vologda, $10-15 \mathrm{~km}$ to Sokol), transport accessibility (the Northern Railway line locates in $0.5-1.5 \mathrm{~km}$ ), and the attractiveness of the facility for picking berries, hunting and recreation, the mire is exposed to strong seasonal recreational impact and associated risk of peat fires. The fires are creeping and local. The last most severe fire here occurred in 2002 was anthropogenically induced and damaged about $8-10 \%$ of the mire area.

Botanical studies of the mire were carried out in 2010, 2012-2014, and 2019. The most material was collected during the 2012 vegetative season near the stopping point of $515 \mathrm{~km}$ of the Northern Railway on three model sites: S1, "natural", i.e. not exposed to direct fire effects, located closer to the centre of the mire (N 59²2'31" E 3958'48") (Fig. 1C); S2, "pyrogenic", exposed in 2002 to the influence of ground fire (N 59²2'30" E 3959'29") (Fig. 1H); S3, 


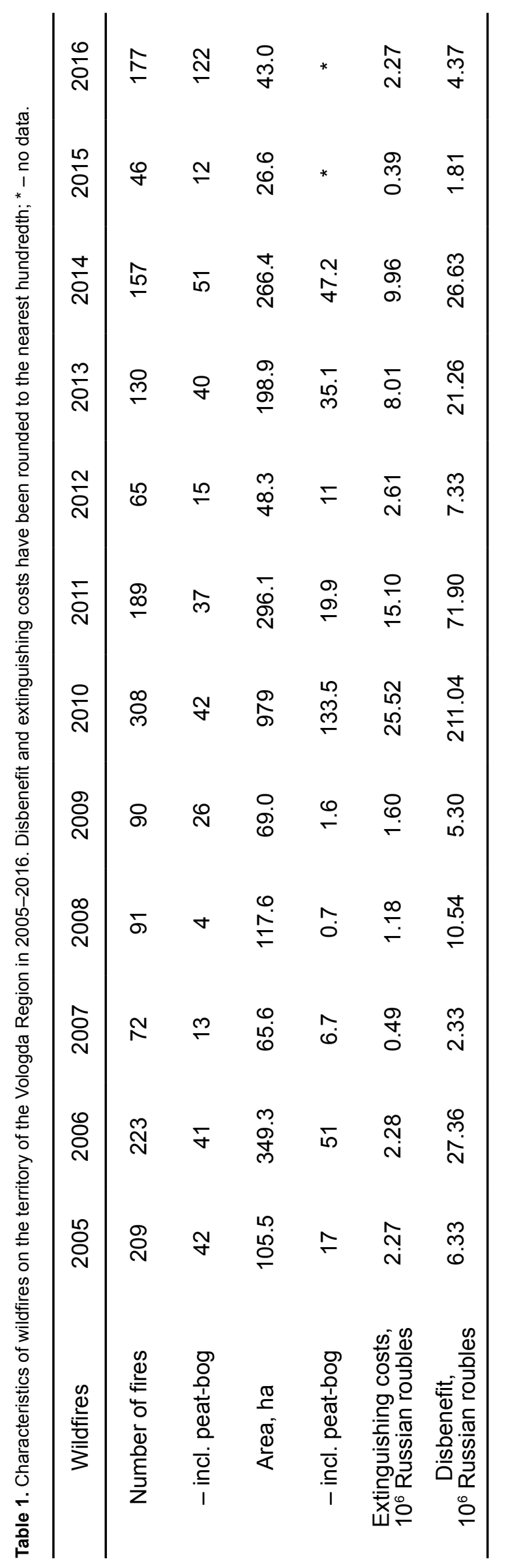


A

B


Fig. 1. The raised bog Barskoe. A - general view of the bog; $\mathbf{B}$ - general view of the pyrogenically transformed site of the mire; $\mathbf{C}-$ pinedwarf shrub-cottongrass-Sphagnum undisturbed site; D - Oxycoccus-cottongrass-Sphagnum communities; $\mathbf{E}$ - traces of fire; $\mathbf{F}-\mathbf{H}$ pyrogenically transformed part of the bog: $\mathbf{F}$ - dying pines after a fire; $\mathbf{G}$ - peat outcrops and the beginning of burnt-out overgrowth with birch and Polytrichum mosses; $\mathbf{H}$ - birch-Polytrichum post-pyrogenic communities. 
"marginal", the forested edge of the mire, not affected by the direct anthropogenic load (N 59 $22^{\prime} 20^{\prime \prime}$ E 3959'31") (Fig. 1B). The emphasis was given to the analysis of changes in flora composition, coenotic diversity and production characteristics of natural and pyrogenically disturbed areas.

In the field, floristic lists were compiled for the entire mire and each part separately (central and marginal natural and pyrogenically disturbed areas), the plants were collected in a herbarium, and the photographs of plants, communities, and the mire areas were taken (Philippov et al., 2017). Geobotanical descriptions were carried out on the plots $(10 \times 10 \mathrm{~m})$ to characterize phytocoenoses. When describing the phytocoenoses, geographic coordinates were recorded (using a Garmin eTrex Vista H GPS receiver), the microrelief shape was described, the water level was determined, the species list was compiled (emphasizing the vascular plants' abundance using the 7-point Brown-Blanquet scale), and the percentage of bryophyte projective cover was assessed. The descriptions were carried out, taking into account the microrelief (ridges, carpet, and hollows were described separately). In order to determine the stock of aboveground biomass, the mowing method was applied (Golovatskaya and Porokhina, 2005). The plots (a metal frame $50 \times 50 \mathrm{~cm}$; five replicates) were analyzed for each microrelief element on natural (hummocks and carpet) and disturbed areas. At each plot, plants were cut at the moss surface level and placed in the plastic bags with labels indicating the site's number, the plot, and the type of microrelief.

The identification of plants, the herbarium setting, compilation of a checklist, digital processing of field materials and their analysis were carried out in the laboratory. Herbarium materials were deposited in the Herbarium of the Department of Biology and Chemistry of the Vologda State University (VO) and the Herbarium of the Mire Research Group, Papanin Institute for Biology of Inland Waters, Russian Academy of Sciences (MIRE). Also, the quantitative samples were grouped by certain species, dried to an air-dry state, then the phytomass and mortmass were weighed (for dwarf shrubs, the photosynthetic (leaves) and non-photosynthetic (branches) parts were weighed separately). The primary data were summarized in tables and analyzed following the data processing recommendations by Golovatskaya and Porokhina (2005).

The plant nomenclature is given in accordance with the recent reviews (Ignatov et al., 2006; Konstantinova et al., 2009; Tsvelev, 2000). Recently, Sphagnum magellanicum Brid. was divided into three species (Hassel et al., 2018), in northern Eurasia, two of them (S. medium Limpr. and S. divinum Flatberg $\&$ Hassel) occur in approximately equal proportions in relatively similar mire biotopes. Considering that these species are sister species, they have not been differentiated during our analysis, so in this study, we follow the accepted approach (Bengtsson et al., 2021) and consider them as S. magellanicum coll. Peat of the medium type is also composed of the remains of this "composite" species.

Floras were compared using the ExcelToR program (Novakovskiy, 2016).

\section{Results and discussion \\ Effect of fires on the flora of higher plants}

In the Barskoe raised bog, 55 species of higher plants were recorded, in particular, Magnoliophyta (32 species), Bryophyta (18), Marchantiophyta (2), Pinophyta (2), and Polypodiophyta (one species), belonging to 36 genera, 26 families, 8 classes, and 5 divisions (Table 2). In the mire flora, the families Sphagnaceae (10 species), Cyperaceae (9), Ericaceae (6), and Salicaceae (four species) dominated. Almost a third of the species list (15 species of vascular plants and 2 moss species) were recorded only at the edge of the mire, and only one species (Pinus sylvestris) was found in all analyzed areas (natural, pyrogenic, and marginal).

As a rule, in the natural areas of the raised bogs, microrelief is well-developed, and the species richness is lower compared to the flora of other types of mires and the combined species list of mire flora (16 species of bryophytes, 13 species of vascular plants). Pinus sylvestris $(\mathrm{h}=2.5-3.5 \mathrm{~m})$, heather dwarf shrubs, Eriophorum vaginatum, Rubus chamaemorus, peat moss (Sphagnum magellanicum coll., S. angustifolium, and S. fuscum) and Polytrichum mosses (Polytrichum strict Dum) grow on hummocks and ridges $(\mathrm{h}=2.5-3.5 \mathrm{~m})$, Drosera rotundifolia and Melampyrum pratense are found less often. Eriophorum vaginatum, Oxycoccus palustris, Scheuchzeria palustris, Carex limosa, peat mosses (Sphagnum balticum, S. angustifolium; rarely, S. cuspidatum, S. majus, and S. fallax) grow on the low carpet and in hollows.

During a fire, complete or partial destruction of the soil and vegetation cover occur, as well as the surface enrichment with ash elements and nitrogen. As a result, the microrelief of the mire area changes; it becomes hummocky with unexpressed complexity. In the Barskoe mire, charred trunks (up to 5-6 m high) and pine stumps remained in the burnt areas. Post-pyrogenic successions are associated with the emergence of shoots of Betula pendula and B. pubescens, the development of Polytrichum mosses (Polytrichum commune, P. strictum), Eriophorum vaginatum, and Calluna vulgaris. Chamaenerion angustifolium is found as single specimens. There are 
Table 2. Species richness and coenotic significance of plants in natural (S1), disturbed by fire (S2), and marginal (S3) areas of the raised bog: 1 - single specimens, 2 - not very abundant, 3 - moderately abundant, 4 - co-dominants, 5 - dominants (very abundant), "-" - the species was not found.

Site

Taxon

S1

S2

S3

Phylum Marchantiophyta

Family Myliaceae Schlijakov

Mylia anomala (Hook.) Gray

1

Family Odontoschismataceae (Grolle) Schlijakov

Cladopodiella fluitans (Nees) $\mathrm{H}$. Buch

1

\section{Phylum Bryophyta}

Family Aulacomniaceae Schimp.

Aulacomnium palustre (Hedw.) Schwägr.

2

1

Family Bryaceae Shwägr.

Bryum sp.

Family Calliergonaceae (Kanda) Vanderp. et al.

Warnstorfia fluitans (Hedw.) Loeske

Family Dicranaceae Schimp.

Dicranum undulatum Schrad. ex Brid.

Family Hylocomiaceae (Broth.) M. Fleisch.

Pleurozium schreberi (Brid.) Mitt.

Family Mielichhoferiaceae Schimp.

Pohlia nutans (Hedw.) Lindb.

Family Polytrichaceae Shwägr.

Polytrichum commune Hedw.

P. strictum Brid.

$-$

3

Family Sphagnaceae Martynov

Sphagnum angustifolium (C.E.O. Jensen ex Russow)

C.E.O. Jensen

S. balticum (Russow) C.E.O. Jensen

\begin{tabular}{lll}
4 & 2 & - \\
4 & - & - \\
2 & - & - \\
2 & - & 2 \\
4 & - & - \\
- & - & 2 \\
5 & 1 & - \\
2 & - & - \\
1 & - & - \\
- & - & 1 \\
\hline
\end{tabular}

S. cuspidatum Ehrh. ex Hoffm.

S. fallax (H.Klinggr.) H. Klinggr.

S. fuscum (Schimp.) H. Klinggr.

S. girgensohnii Russow

S. magellanicum coll.

S. majus (Russow) C.E.O. Jensen

S. rubellum Wilson

S. russowii Warnst.

Phylum Polypodiophyta

Family Dryopteridaceae Ching 


\begin{tabular}{|c|c|c|c|}
\hline \multirow[b]{2}{*}{ Taxon } & \multicolumn{3}{|c|}{ Site } \\
\hline & $\mathrm{S} 1$ & $\mathrm{~S} 2$ & S3 \\
\hline \multicolumn{4}{|l|}{ Phylum Pinophyta } \\
\hline \multicolumn{4}{|l|}{ Family Pinaceae Lindl. } \\
\hline Picea abies (L.) Karst. & - & - & 1 \\
\hline Pinus sylvestris L. & 5 & 2 & 2 \\
\hline \multicolumn{4}{|l|}{ Phylum Magnoliophyta } \\
\hline \multicolumn{4}{|l|}{ Family Betulaceae S.F. Gray } \\
\hline Alnus incana (L.) Moench & - & - & 2 \\
\hline Betula pendula Roth & - & 5 & 3 \\
\hline B. pubescens Ehrh. & - & 3 & 2 \\
\hline \multicolumn{4}{|l|}{ Family Cyperaceae Juss. } \\
\hline Carex acuta L. & - & - & 1 \\
\hline C. canescens $\mathrm{L}$. & - & - & 2 \\
\hline C. echinata Murr. & - & - & 2 \\
\hline C. limosa L. & 3 & - & - \\
\hline C. pauciflora Lightf. & 2 & - & - \\
\hline C. rostrata Stokes & - & - & 2 \\
\hline C. vesicaria $\mathrm{L}$. & - & - & 1 \\
\hline Eriophorum vaginatum $\mathrm{L}$. & 5 & 4 & - \\
\hline Scirpus sylvaticus L. & - & - & 1 \\
\hline \multicolumn{4}{|l|}{ Family Droseraceae Salisb. } \\
\hline Drosera rotundifolia L. & 2 & 3 & - \\
\hline \multicolumn{4}{|l|}{ Family Ericaceae Juss. } \\
\hline Andromeda polifolia L. & 5 & 2 & - \\
\hline Calluna vulgaris (L.) Hull & - & 4 & - \\
\hline Chamaedaphne calyculata (L.) Moench & 5 & 2 & - \\
\hline Ledum palustre L. & 2 & 4 & - \\
\hline Oxycoccus palustris Pers. & 4 & 4 & - \\
\hline Vaccinium uliginosum $\mathrm{L}$. & 3 & 3 & - \\
\hline \multicolumn{4}{|l|}{ Family Onagraceae Juss. } \\
\hline Chamaenerion angustifolium (L.) Scop. & - & 1 & 2 \\
\hline \multicolumn{4}{|l|}{ Family Pediculariaceae Juss. } \\
\hline Melampyrum pratense L. & 1 & 1 & - \\
\hline \multicolumn{4}{|l|}{ Family Poaceae Barnhart } \\
\hline Deschampsia caespitosa (L.) Beauv. & - & 1 & 1 \\
\hline \multicolumn{4}{|l|}{ Family Ranunculaceae Juss. } \\
\hline Ranunculus repens $\mathrm{L}$. & - & - & 2 \\
\hline \multicolumn{4}{|l|}{ Family Rhamnaceae Juss. } \\
\hline Frangula alnus Mill. & - & - & 1 \\
\hline
\end{tabular}




\begin{tabular}{|c|c|c|c|}
\hline \multirow{2}{*}{ Taxon } & \multicolumn{3}{|c|}{ Site } \\
\hline & s1 & S2 & S3 \\
\hline \multicolumn{4}{|l|}{ Family Grossulariaceae DC. } \\
\hline Ribes nigrum L. & - & - & 2 \\
\hline \multicolumn{4}{|l|}{ Family Rosaceae Juss. } \\
\hline Rubus chamaemorus L. & 4 & 2 & - \\
\hline \multicolumn{4}{|l|}{ Salicaceae Mirb. } \\
\hline Populus tremula L. & - & 2 & 2 \\
\hline Salix caprea L. & - & - & 2 \\
\hline S. cinerea L. & - & 1 & 2 \\
\hline S. pentandra L. & - & - & 2 \\
\hline \multicolumn{4}{|c|}{ Family Scheuchzeriaceae F. Rudolphi } \\
\hline Scheuchzeria palustris L. & 4 & - & - \\
\hline \multicolumn{4}{|l|}{ Family Typhaceae Juss. } \\
\hline Typha latifolia L. s.I. & - & - & 2 \\
\hline Total number of species & 29 & 24 & 27 \\
\hline
\end{tabular}

practically no hygrophilic species (peat mosses), but some species characteristic for the marginal areas and adjacent mineral lands (Salix cinerea, Populus tremula) begin to occur. In total, 17 species of vascular plants and 7 species of mosses were found in the flora of peat bog areas recovering from a fire. The leading families are Ericaceae (6 species), Polytrichaceae, Sphagnaceae, Betulaceae, and Salicaceae (2 species each). The similarity of the natural and pyrogenic areas' floras based on the Sørensen-Czekanowski coefficient is low (0.56), and the similarity of these two areas with the marginal flora is even lower (0.20). In the marginal areas of the raised bog, 27 species were found (22 species of vascular plants, 5 species of mosses). The marginal flora is mostly presented by forest, mire-forest, and mire-meadow species; this is also typical for other mires in the region (Philippov, 2015) and is associated with the edge effect, but not with anthropogenic transformations of the territory.

In general, after the fire in the raised bog, the number of species decreases insignificantly (from 29 to 24); however, the proportions of certain groups change: the share of typical mire plants, hygrophytes (Sphagnum spp., Carex spp.) decreases, the share of meso- and xerophilic species increases, and such species as Betula spp., Populus tremula, Calluna vulgaris, Chamaenerion angustifolium appear. Similar trends (leaving the regional characteristics) were reported by other researchers (Denisenkov, 1980; Grummo et al., 2010; Napreenko, 2002; Pyavchenko, 1955, etc.).

\section{Effect of fires \\ on the coenotic diversity}

Not all the plant species play the same role in plant communities' composition (Table 2). The analyzed areas are characterized by low species similarity. Thus, the natural and pyrogenic sites are similar in terms of species abundance and composition (Sørensen-Czekanowski index is 0.36), and the similarity of these two sites with the mire margin is even lower (0.13).

Out of 29 species of higher plants growing in natural sites, only 8 species are the most coenotically significant (considering the microrelief); these are Pinus sylvestris, Eriophorum vaginatum, Andromeda polifolia, Chamaedaphne calyculata, Sphagnum magellanicum coll., S. balticum, S. angustifolium, and $S$. fuscum. On hummocks, they form pineChamaedaphne-Sphagnum and pine-AndromedaSphagnum communities, in hollows, ScheuchzeriaSphagnum, sedge-Scheuchzeria-Sphagnum, Scheuchzeria-Oxycoccus-Sphagnum, on the carpet, cottongrass-Sphagnum-Oxycoccus communities.

At the initial stages of the post-pyrogenic restoration of the peat bog, the central role is played by Polytrichum commune, as well as Eriophorum vaginatum and two species of birch trees (Betula pendula and $B$. pubescens). Depending on specific conditions, they form Polytrichum, cottongrassPolytrichum, and/or birch-Polytrichum communities. Meantime, in the studied areas, birch should be considered only as undergrowth, but not as a tree layer, 
since the height of $B$. pendula reaches an average of $1.5-1.8 \mathrm{~m}, B$. pubescens, usually no more than $0.6 \mathrm{~m}$. Liverworts were not found in disturbed areas of the mire, although Marchantia polymorpha L. aggr. may be found on the burnt places according to some authors (Napreenko, 1996).

In general, under the influence of the pyrogenic factor, the coenotic structure of the Barskoe raised bog has simplified significantly:

1) in the tree layer, pine is replaced by birch (mainly B. pendula);

2) in the grass-dwarf shrub layer, the importance of some heather dwarf shrubs (Calluna vulgaris, Ledum palustre) increases, while Andromeda polifolia and Chamaedaphne calyculata are almost absent;

3 ) environment-forming plant species of natural mires (Sphagnum spp.) are almost entirely replaced by Polytrichum mosses (Polytrichum commune, $P$. strictum); this reduces the rate of carbon accumulation in peat deposits due to the loss of the main peat-forming species.

Similar results were obtained by other scientists. The research performed in 1951 in the Totma District of the Vologda Region evidenced that the tree layer also underwent restoration mainly due to birch and aspen, the moss cover was represented by Polytrichum commune, while in the wetter sites of the burnt places, Sphagnum capillifolium (Ehrh.) Hedw., S. fallax, and S. balticum could be found (Pyavchenko, 1955). When studying pyrogenic successions in the Cherepovets District of the Vologda Region, it was also noted that after some time, shoots of Betula ssp. and Ledum palustre developed on the burnt places; Eriophorum vaginatum, Vaccinium uliginosum, and Andromeda polifolia were fruiting actively; Calluna vulgaris, Chamaenerion angustifolium, and Epilobium palustre appeared; and peat mosses were replaced by Polytrichum strictum and Marchantia polymorpha (Denisenkov, 1980).

Such a birch-dwarf shrub-moss stage may last for 30-40 years, but it may be shortened when the total humidity increases, which, in turn, initiates the beginning of the restoration of the Sphagnum cover (Sejbutis, 1961). Other authors believe that the restoration of oligotrophic mire vegetation is associated with a decrease in the amount of nitrogen accumulated in the upper layers of peat after a fire (Popov, 2000). However, only a slight increase in the content of nitrogen and phosphorus is noted in post-pyrogenic peat soils; therefore, an increase in the mire soil fertility is mostly due to a decrease in moisture, destruction of moss cover, and an increased concentration of ash elements (Akhmetyeva et al., 2011; Efremova and Efremov, 1994). Further overgrowth of these areas reduces the trophicity of the upper soil layers. Improving mineral nutrition promotes active regeneration; for example, this is true for Eriophorum vaginatum (Grishutkin, 2012).

Fires in the mires of the Kaliningrad Region (Napreenko, 2002) and Belarus (Grummo et al., 2010) lead to a depletion of the species composition, thinning of the tree layer, active development of deciduous forest-forming species, an increase in the coenotic significance of Calluna vulgaris and Polytrichum strictum, and a weak renewal of hygrophytes. All researchers noted an increase in mires vulnerability to fires with a decrease in their moisture supply.

\section{Effect of fires on the aboveground plant biomass}

Biological productivity (the ability of living organisms to create, preserve, and transform organic matter) consists of three main indicators: biomass stock, dynamics of phytomass growth, and net primary production (Golovatskaya and Porokhina, 2005). During our research, the primary attention was paid to the stock of aboveground biomass at three sampling sites (their geobotanical description is given in Table 3).

In oligotrophic mire areas with a ridge-carpet microrelief (S1a, Table 3), the aboveground biomass stock in the pine-Chamaedaphne-Sphagnum community of the ridge is $1225 \mathrm{~g} / \mathrm{m}^{2}$ (Table 4). The most important role is played by $S$. magellanicum coll. $\left(417 \mathrm{~g} / \mathrm{m}^{2}\right)$ and $S$. fuscum $\left(134 \mathrm{~g} / \mathrm{m}^{2}\right)$, Chamaedaphne calyculata $\left(82 \mathrm{~g} / \mathrm{m}^{2}\right.$, photosynthesizing part; $242 \mathrm{~g} / \mathrm{m}^{2}$, non-photosynthesizing part), Oxycoccus palustris (32 and $43 \mathrm{~g} / \mathrm{m}^{2}$, respectively). Andromeda polifolia, Ledum palustre, Vaccinium uliginosum, and Aulacomnium palustre have a minor contribution to the total biomass (from < 1 to $3 \mathrm{~g} / \mathrm{m}^{2}$ ). Mortmass (litter) is $174 \mathrm{~g} / \mathrm{m}^{2}$; its share in the total biomass stock is $14.2 \%$. The phytomass of the moss layer $\left(572 \mathrm{~g} / \mathrm{m}^{2}\right)$ in the ridge communities of the Barskoe raised bog is 1.5 times higher than the phytomass of grasses and dwarf shrubs $\left(384 \mathrm{~g} / \mathrm{m}^{2}\right)$. The non-photosynthesizing phytomass exceeds the photosynthetic phytomass in the grassdwarf shrub layer almost twofold (branches, $254 \mathrm{~g} / \mathrm{m}^{2}$; leaves and grasses, $130 \mathrm{~g} / \mathrm{m}^{2}$ ).

In the same ridge-carpet complex, in the cottongrass-Oxycoccus-Sphagnum carpet community (S1b, Table 3), the biomass stock is $963 \mathrm{~g} / \mathrm{m}^{2}$ (Table 4). The highest biomass is typical for $S$. angustifolium $\left(623 \mathrm{~g} / \mathrm{m}^{2}\right)$, Eriophorum vaginatum $\left(53 \mathrm{~g} / \mathrm{m}^{2}\right)$, Oxycoccus palustris (photosynthesizing part, $42 \mathrm{~g} / \mathrm{m}^{2}$; non-photosynthesizing part, $55 \mathrm{~g} / \mathrm{m}^{2}$ ). The minimum biomass was recorded in Andromeda polifolia (photosynthesizing part, $6 \mathrm{~g} / \mathrm{m}^{2}$; non-photosynthesizing part, $3 \mathrm{~g} / \mathrm{m}^{2}$ ). There are practically no species characteristic of hummocks and ridges of raised bogs among the plants that form the bulk of biomass in carpet communities. Mortmass (litter) is $182 \mathrm{~g} / \mathrm{m}^{2}$, 
Table 3. Vegetation of natural ( $\mathrm{S} 1 \mathrm{a}$ - ridge, $\mathrm{S} 1 \mathrm{~b}$ - carpet) and disturbed by fire (S2) areas of the raised bog. For vascular plants, the abundance is indicated in points; for bryophytes, as projective cover, \%; for woody plants, the height $(\mathrm{m})$ is given in brackets.

\begin{tabular}{|c|c|c|c|}
\hline & \multicolumn{3}{|c|}{ Community } \\
\hline & S1a & $\mathrm{S} 1 \mathrm{~b}$ & S2 \\
\hline Total projective cover, $\%$ & 95 & 95 & $75-80$ \\
\hline Phreatic line, $\mathrm{cm}$ & $-18 \ldots-20$ & $-7 \ldots-8$ & $-20 \ldots-25$ \\
\hline Number of species & 17 & 10 & 20 \\
\hline \multicolumn{4}{|l|}{ Tree and dwarf shrubs layer } \\
\hline Betula pendula & - & - & $3(1.5-1.8)$ \\
\hline Betula pubescens & - & - & $1(0.5-0.6)$ \\
\hline Pinus sylvestris & $1(2.5-3.5)$ & - & $+(0.5)$ \\
\hline Populus tremula & - & - & $+(0.3-0.4)$ \\
\hline Andromeda polifolia & + & + & + \\
\hline Calluna vulgaris & - & - & $\mathrm{r}$ \\
\hline Chamaedaphne calyculata & 3 & + & + \\
\hline Ledum palustre & - & r & - \\
\hline Oxycoccus palustris & 2 & 2 & + \\
\hline Rubus chamaemorus & 2 & + & + \\
\hline Vaccinium uliginosum & 1 & - & 1 \\
\hline \multicolumn{4}{|l|}{ Grass and moss layer } \\
\hline Drosera rotundifolia & r & - & - \\
\hline Eriophorum vaginatum & 1 & 4 & 2 \\
\hline Melampyrum pratense & - & - & r \\
\hline Aulacomnium palustre & $2-3$ & - & $3-4$ \\
\hline Bryum sp. & - & - & $1-2$ \\
\hline Dicranum undulatum & $1-2$ & - & - \\
\hline Pleurozium schreberi & $1-2$ & - & $1-2$ \\
\hline Pohlia nutans & $1-2$ & - & $1-2$ \\
\hline Polytrichum commune & - & - & $65-70$ \\
\hline Polytrichum strictum & $5-7$ & - & $25-30$ \\
\hline Sphagnum angustifolium & 15 & 15 & $10-12$ \\
\hline S. balticum & - & 65 & - \\
\hline S. fuscum & 30 & $2-3$ & - \\
\hline S. magellanicum coll. & 30 & $5-7$ & $1-2$ \\
\hline Mylia anomala & $1-2$ & - & - \\
\hline
\end{tabular}


and its share of the total biomass stock is $18.9 \%$. In carpet communities, the phytomass value of the moss layer $\left(623 \mathrm{~g} / \mathrm{m}^{2}\right)$ exceeds that in the grass-dwarf shrub layer almost fourfold $\left(158 \mathrm{~g} / \mathrm{m}^{2}\right)$. Meantime, the photosynthesizing phytomass is 1.6 times higher than that of non-photosynthetic phytomass (leaves and grass, $97 \mathrm{~g} / \mathrm{m}^{2}$; branches, $61 \mathrm{~g} / \mathrm{m}^{2}$ ).

In the pyrogenically disturbed site of the mire, in the birch-Polytrichum community (S2, Table 3), the biomass stock is $1725 \mathrm{~g} / \mathrm{m}^{2}$, which exceeds that in the mire areas untouched by the fire in 1.4-1.8 times (Table 4). Polytrichum commune $\left(473 \mathrm{~g} / \mathrm{m}^{2}\right)$ and Eriophorum vaginatum $\left(50 \mathrm{~g} / \mathrm{m}^{2}\right)$ play the central role in these communities. The other species (Andromeda polifolia, Oxycoccus palustris, Vaccinium uliginosum, Aulacomnium palustre, Sphagnum angustifolium, and S. fuscum) are characterized by minimal biomass stock $\left(1-10 \mathrm{~g} / \mathrm{m}^{2}\right)$. Mortmass (mat) is $1173 \mathrm{~g} / \mathrm{m}^{2}$; its share in the total biomass stock is $68 \%$. The phytomass of the moss layer in the pyrogenically disturbed communities $\left(488 \mathrm{~g} / \mathrm{m}^{2}\right)$ is 8.1 times higher than that of the grass-dwarf shrub layer $\left(60 \mathrm{~g} / \mathrm{m}^{2}\right)$. Meantime, the proportion of photosynthesizing phytomass exceeds that of non-photosynthesizing elevenfold (leaves and grass, $55 \mathrm{~g} / \mathrm{m}^{2}$; branches, $5 \mathrm{~g} / \mathrm{m}^{2}$ ).

In addition to absolute biomass values, it is necessary to pay attention to the aboveground biomass stocks' distributional pattern, i.e. their fraction composition (Table 4). In the natural part of the mire, the central role in the biomass structure belongs to the photosynthetic phytomass. In particular, its share exceeds $60 \%\left(754 \mathrm{~g} / \mathrm{m}^{2}\right)$ on the ridges and almost $75 \%\left(720 \mathrm{~g} / \mathrm{m}^{2}\right)$ on the carpet. The main difference in the biomass structure between these elements of the ridge-carpet complex is that there are practically no heather dwarf shrubs on the carpet. Accordingly, the share of non-photosynthesizing phytomass on the ridges $\left(298 \mathrm{~g} / \mathrm{m}^{2}\right)$ is 4.9 times higher than that on the carpet $\left(61 \mathrm{~g} / \mathrm{m}^{2}\right)$. The mortmass in the mire area undisturbed by the fire is insignificant and ranges as $14-19 \%$ of the total biomass stock $\left(174 \mathrm{~g} / \mathrm{m}^{2}\right.$ on the ridges, $182 \mathrm{~g} / \mathrm{m}^{2}$ on carpet). A completely different distribution of biomass is observed in the communities of pyrogenically disturbed areas when only one third belongs to photosynthetic phytomass (543 $\mathrm{g} / \mathrm{m}^{2}$, mainly due to Polytrichum commune), and mortmass accounts for up to $68 \%$ of the total biomass stock. In the disturbed areas, the role of peat mosses, the main peat-formers in the raised bogs, decreases to almost zero.

In general, peat fires also change the production parameters of the raised bog communities. Thus, the stock of dry biomass of pyrogenically disturbed areas increases in 1.4-1.8 times compared to the biomass of ridges and carpet of natural communities, but the share of photosynthetic phytomass decreases by $30-40 \%$, and the share of mortmass increases in 6.4-
6.7 times. Since the photosynthesizing phytomass of undisturbed raised bogs is presented mainly of peat mosses, its reduction leads to a decrease in the rate of peat accumulation and an increase in carbon emission.

Similar trends were reported by other authors. Long-term observations of the dynamics of the aboveground phytomass in the post-pyrogenic period in a mesotrophic dwarf shrub-Sphagnum mire in the Far East Region of Russia evidenced that the structure of the living phytomass of vascular plants in an undisturbed area was constant: dwarf shrubs, 87\%; herbaceous, 13\% (Kopoteva and Kuptsova, 2016). When omitting the microrelief and considering the natural mire area as a whole in our studies, the ratio of dwarf shrubs to herbaceous plants was 9 to 1 . There was also indicated that the share of herbaceous plants began to increase in the burnt place compared to that of dwarf shrubs (Kopoteva and Kuptsova, 2016); this was due to grasses' ability to grow annually, while dwarf shrubs tended to restrict growth after they reached 5-6 years.

A tendency to an increase in the share of mortmass in the total biomass was noted both when studying the effects of fires on the mires of the Far East Region of Russia (Kopoteva and Kuptsova, 2016) and in our study; however, absolute values obtained for the Barskoe raised bog were significantly higher $\left(1173 \mathrm{~g} / \mathrm{m}^{2}\right.$ versus $\left.42 \mathrm{~g} / \mathrm{m}^{2}\right)$. It was probably due to a different understanding of the scale and interpretation of the term "mortmass" rather than the mire type or geographical position of the mire.

\section{Possible scenarios for further community succession}

At this point, we cannot unambiguously determine further changes in the three analyzed areas. However, in many respects, they will depend on climatic factors, since the raised bog has an atmospheric type of water-mineral nutrition, and anthropogenic factors, such as the strength of possible fires and nature of the further mire use.

We assume that the natural site will continue to progress towards differentiation of the surface into microforms, forming ridge-hollow complexes, will continue as well. The water content in the hollows (and their further evolution into lakelets) will largely depend on the region's climate (primarily humidity). Global warming will have a negative impact on this process; however, it will contribute to an increase in biological productivity and the degree of participation of tree species in mire coenoses.

The pyrogenic site will continue to recover, but in many respects, the rate of this process will be preconditioned by the water content and by a decrease of the trophicity of the site (due to a decrease in the ash content of peat, which increases during a fire). Likely, the main observed changes are associated 


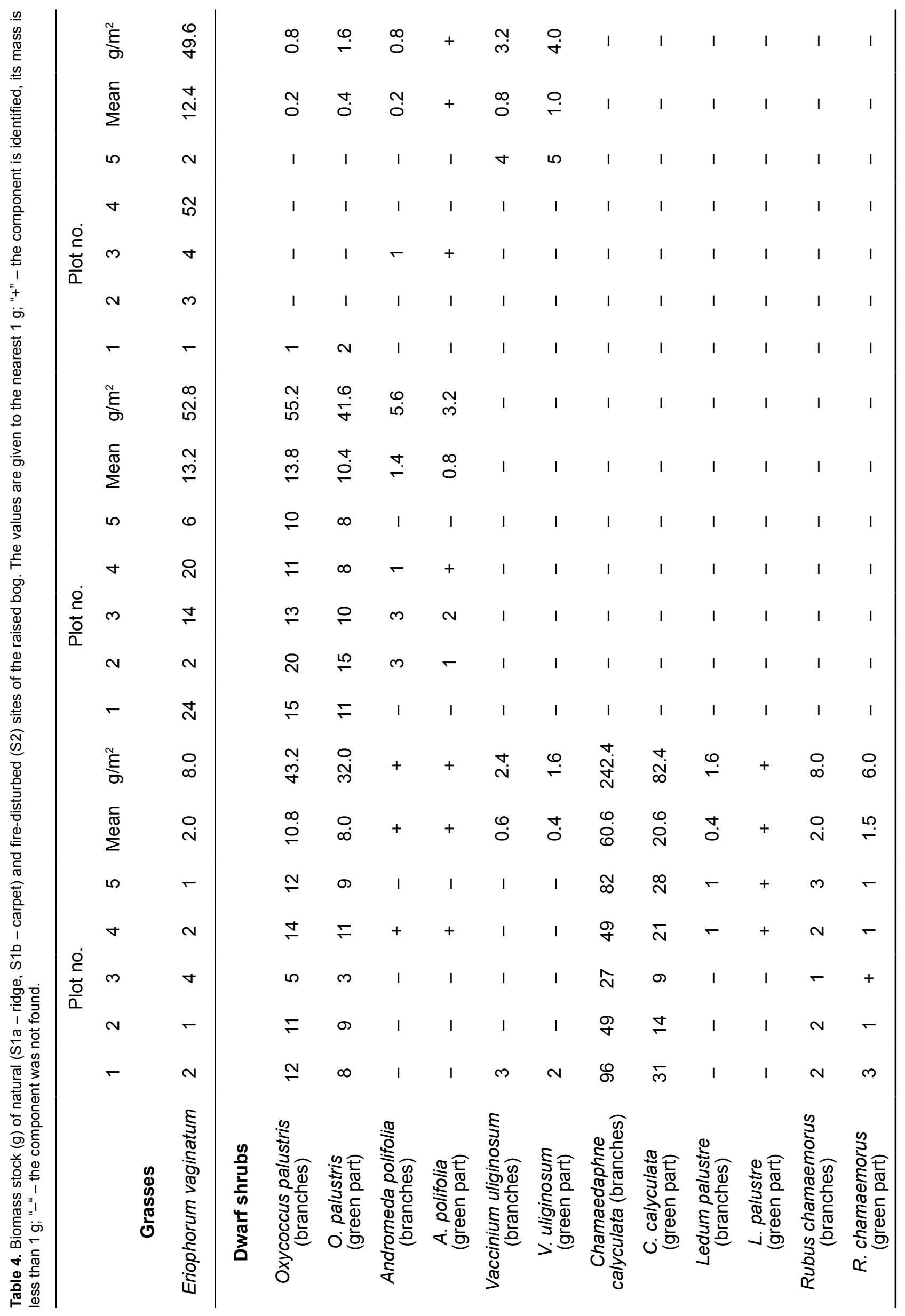




\begin{tabular}{|c|c|c|c|c|c|c|c|c|c|c|c|c|c|c|c|}
\hline & है & 1 & $\stackrel{\circ}{+}$ & & $\stackrel{0}{-}$ & $\stackrel{\oplus}{\circ}$ & 1 & $\stackrel{\circ}{\dot{\forall}}$ & 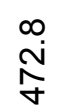 & 1 & $\begin{array}{l}\stackrel{\infty}{N} \\
\stackrel{N}{\Sigma}\end{array}$ & $\stackrel{\infty}{\dot{\forall}}$ & $\begin{array}{l}\stackrel{N}{~} \\
\mathscr{V}\end{array}$ & $\begin{array}{l}\text { ¿্ర } \\
\text { న }\end{array}$ & $\begin{array}{l}\infty \\
\underset{\mathbb{N}}{N}\end{array}$ \\
\hline & $\begin{array}{l}\frac{\sqrt{\mathbb{N}}}{\mathbb{D}} \\
\stackrel{\mathbb{d}}{\Sigma}\end{array}$ & 1 & $\stackrel{\circ}{r}$ & & $\stackrel{+}{\circ}$ & $\stackrel{\stackrel{\sim}{i}}{\Delta}$ & 1 & $\stackrel{\circ}{r}$ & $\stackrel{\sim}{\infty}$ & 1 & $\begin{array}{l}\text { N } \\
\text { న }\end{array}$ & $\stackrel{\sim}{\sim}$ & $\begin{array}{l}\infty \\
\stackrel{\infty}{\infty} \\
\stackrel{m}{\longrightarrow}\end{array}$ & $\stackrel{\text { ণ }}{\infty}$ & $\frac{\sim}{\stackrel{m}{\sigma}}$ \\
\hline & م & 1 & 1 & & 1 & $\mp$ & 1 & 1 & ঙे & I & 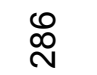 & $\nabla$ & N. & ஓి & $\stackrel{\mathscr{Y}}{\forall}$ \\
\hline & $\nabla$ & 1 & 1 & & + & 1 & 1 & 10 & $\stackrel{ }{F}$ & I & లे & 0 & $\underset{\sim}{\stackrel{N}{\sigma}}$ & 尺ి & $\frac{10}{10}$ \\
\hline 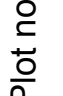 & $m$ & 1 & 1 & & 1 & $r$ & 1 & 1 & $\stackrel{+}{6}$ & 1 & స్లి & - & 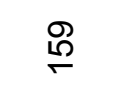 & ঃి & $\stackrel{N}{i}$ \\
\hline & $\sim$ & 1 & 1 & & $N$ & 1 & 1 & 1 & $\stackrel{\mathscr{O}}{\underset{\sim}{*}}$ & 1 & $\widehat{N}$ & 0 & $\stackrel{5}{5}$ & 유 & $\begin{array}{l}\infty \\
\infty \\
\infty\end{array}$ \\
\hline & $r$ & 1 & 10 & & 1 & 1 & 1 & 1 & 웅 & 1 & 융 & $r$ & $\stackrel{\mathscr{f}}{\forall}$ & ి. & \&্ন \\
\hline & है & + & 1 & & + & $\begin{array}{l}\text { N̦ } \\
\text { స్ర }\end{array}$ & 1 & 1 & 1 & 1 & 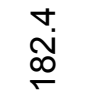 & $\begin{array}{l}\infty \\
\stackrel{0}{0} \\
0\end{array}$ & 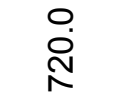 & $\begin{array}{l}\text { ్․ } \\
\text { గ్ర }\end{array}$ & $\begin{array}{l}\text { Na } \\
\text { ర్రి }\end{array}$ \\
\hline & 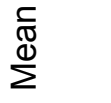 & + & 1 & & + & $\begin{array}{l}\infty \\
\stackrel{\infty}{\circ} \\
\stackrel{n}{\Gamma}\end{array}$ & 1 & 1 & 1 & 1 & $\begin{array}{l}\varphi \\
\dot{\varphi}\end{array}$ & ָุ & \begin{tabular}{l}
$\circ$ \\
$\stackrel{0}{\infty}$ \\
\hdashline
\end{tabular} & $\begin{array}{l}\stackrel{\infty}{\infty} \\
\stackrel{N}{N}\end{array}$ & 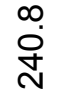 \\
\hline & ما & + & 1 & & 1 & $\stackrel{+}{5}$ & 1 & 1 & 1 & I & $\stackrel{\oplus}{N}$ & 음 & $\stackrel{\infty}{\varrho}$ & $\frac{8}{\text { 은 }}$ & ષ્ণ \\
\hline & $\nabla$ & 1 & 1 & & + & $\stackrel{\stackrel{\circ}{N}}{\sim}$ & 1 & 1 & 1 & I & চ & $\stackrel{\sim}{\leftarrow}$ & مొ & 올 & 吕 \\
\hline 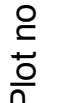 & $m$ & + & 1 & & 1 & ๙ิ & 1 & 1 & 1 & 1 & ㅇ & $\stackrel{\bullet}{\circ}$ & $\stackrel{\infty}{\sim}$ & ষ্ণ & ఫ్లి \\
\hline & $\sim$ & + & 1 & & 1 & $\stackrel{\text { P }}{\leftarrow}$ & 1 & 1 & 1 & 1 & $\stackrel{\infty}{\leftarrow}$ & $\stackrel{\mathscr{N}}{ }$ & $\hat{\oplus}$ & $\frac{8}{\text { 은 }}$ & $\stackrel{\infty}{\text { ¿ }}$ \\
\hline & - & 1 & 1 & & 1 & 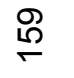 & 1 & 1 & 1 & 1 & 尺 & $\stackrel{5}{\sim}$ & $\stackrel{\text { ğ }}{\leftarrow}$ & ষ্ల & $\stackrel{\mathbb{N}}{\text { N }}$ \\
\hline & క్ & + & 1 & & $\stackrel{\infty}{0}$ & $\begin{array}{l}\infty \\
\stackrel{N}{ }\end{array}$ & $\begin{array}{l}\infty \\
\stackrel{\infty}{0} \\
\stackrel{\sigma}{\sigma}\end{array}$ & $\begin{array}{l}\stackrel{0}{\oplus} \\
\stackrel{m}{\sim}\end{array}$ & 1 & $\begin{array}{l}\infty \\
\text { Ni}\end{array}$ & $\begin{array}{l}\stackrel{0}{M} \\
\stackrel{M}{\alpha}\end{array}$ & $\begin{array}{l}0 \\
\infty \\
\stackrel{\infty}{N}\end{array}$ & $\begin{array}{l}\stackrel{0}{~} \\
\text { مُ } \\
\stackrel{م}{N}\end{array}$ & $\begin{array}{l}\stackrel{0}{0} \\
\text { న }\end{array}$ & 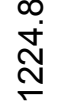 \\
\hline & 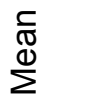 & + & 1 & & $\stackrel{N}{0}$ & ஸั & $\begin{array}{l}\stackrel{N}{O} \\
\stackrel{0}{\circ}\end{array}$ & $\stackrel{\oplus}{\ddot{m}}$ & 1 & $\stackrel{\sim}{\stackrel{M}{\sim}}$ & $\stackrel{\forall}{\stackrel{P}{\sigma}}$ & 莳 & $\begin{array}{l}\stackrel{+}{0} \\
\infty \\
\infty \\
-\end{array}$ & 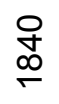 & $\begin{array}{l}\text { N } \\
\ddot{\delta}\end{array}$ \\
\hline & 10 & 1 & 1 & & + & $\mp$ & $\stackrel{\text { I }}{\circ}$ & L & 1 & $r$ & $\mathscr{C}$ & $\infty$ & $\stackrel{\circ}{\circ}$ & 옫 & $\underset{\text { స్ }}{\stackrel{\sim}{~}}$ \\
\hline & $\nabla$ & 1 & 1 & & 1 & $\mp$ & $\stackrel{N}{E}$ & $\stackrel{F}{\digamma}$ & 1 & 1 & గి & $\bigoplus$ & $\stackrel{\infty}{-}$ & ஓ & ஜి \\
\hline 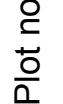 & $m$ & + & 1 & & 1 & $\nabla$ & $\widehat{\infty}$ & $R$ & 1 & $\sim$ & @్ల & m & $\stackrel{9}{\frac{9}{2}}$ & ষ্ণ & $\stackrel{\infty}{\sim}$ \\
\hline & $\sim$ & + & 1 & & 1 & 1 & $\stackrel{8}{-}$ & 8 & 1 & $r$ & $\stackrel{ }{-}$ & ชิ & ๙ু & $\underset{\infty}{\infty}$ & త్ర \\
\hline & $r$ & 1 & 1 & & $r$ & 1 & 응 & $\stackrel{L}{\sim}$ & 1 & $\widetilde{0}$ & $\mathscr{Q}$ & $\stackrel{m}{\rightleftharpoons}$ & $\stackrel{\grave{N}}{\sim}$ & ৪ి & 요 \\
\hline & 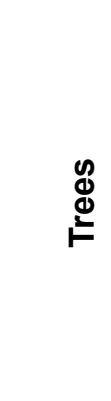 & 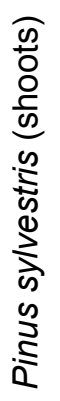 & 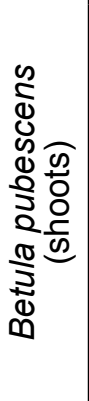 & 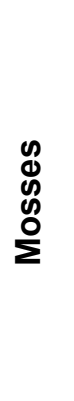 & 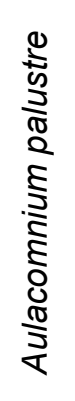 & 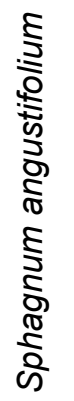 & 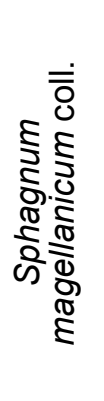 & $\begin{array}{l}5 \\
5 \\
0 \\
5 \\
\frac{5}{2} \\
5 \\
5 \\
5 \\
D \\
\frac{D}{2} \\
\omega\end{array}$ & 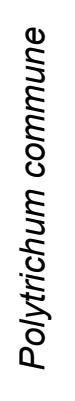 & 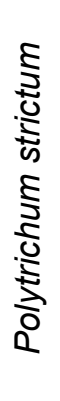 & 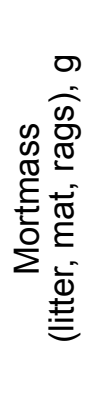 & 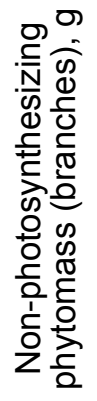 & 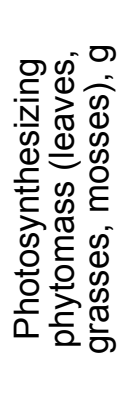 & 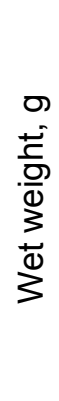 & 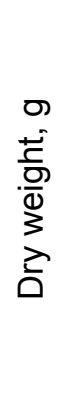 \\
\hline
\end{tabular}


with the introduction of peat mosses and Pinus sylvestris into the coenoses, as well as with the loss of Betula pubescens, B. pendula, and other species uncharacteristic for the raised bogs (Populus tremula, Salix cinerea, Chamaenerion angustifolium, and Deschampsia caespitosa) from the communities.

The marginal area of the mire is least susceptible to global processes; therefore, its further development depends on the local factors only. For example, in the case of increasing recreational load, the introduction of weed or invasive species is possible.

\section{Conclusions}

Fires in the raised bogs affect the species richness, the structure of phytocoenoses, and the rate of biomass accumulation. By the example of the Barskoe raised bog, we argue that in 10-12 years after the ground fire has occurred, the pyrogenically disturbed areas differ from the natural mire complexes, which have not been directly exposed to fire. Post-pyrogenic changes in the canopy cover of the raised bog are associated with a slight decrease in the species richness, the loss of moisture-demanding mire species, a simplification of the structure of the mire areas, a decrease in coenotic diversity, an increase in dry biomass accompanied by a decrease in photosynthetic phytomass by $30-40 \%$, and with an increase of the mortmass in 6.4-6.7 times. Accelerating the rate of restoration of the raised bog ecosystem is possible due to the prevention of new fires and increasing the overall water content of the mire.

\section{Acknowledgments}

The authors are grateful to A.V. Ivanov for his help with sorting of cut samples by fractions and V.V. Yurchenko (IBIW RAS) for her help during the fieldwork in 2010, as well as anonymous reviewers for valuable comments and advices.

\section{Funding}

The research of D.A. Philippov completed in the framework of the state assignment of Papanin Institute for Biology of Inland Waters Russian Academy of Sciences (project no. AAAA-A18-118012690099-2).

\section{ORCID}

Dmitriy A. Philippov (D) 0000-0003-3075-1959

\section{References}

Abramova, T.G., 1965. Bolota Vologodskoy oblasti, ikh rayonirovanie i sel'skokhozyaystvennoe ispol'zovanie [Mires of the Vologda Region, their regionalization and agricultural use]. Severo-Zapad evropeyskoy chasti SSSR [North-West European part of the USSR] 4, 65-93 (In Russian).

Akhmetyeva, N.P., Lapina, E.E., Mikhailova, A.V., 2011. Izmenenie khimicheskogo sostava bolotnykh vod posle pozharov 2010 goda (na primere vodosbora Ivan'kovskogo vodokhranilishcha) [Change of the chemical compound of peat waters after fires of 2010 (on the example of water catchment area of the Ivankovsky water reservoir)]. Trudy Instorfa [Proceedings of East European Institute of Peat] 4, 12-17. (In Russian).

Akmet'eva, N.P., Belova, S.E., Dzhamalov, R.G., Kulichevskaya, I.S., Lapina, E.E., Mikhailova, A.V., 2014. Natural post-fire bog recovery. Water Resources 41 (4), 353-363. https://doi.org/10.1134/ S0097807814040022

Bengtsson, F., Rydin, H., Baltzer, J.L., Bragazza, L., $\mathrm{Bu}, \mathrm{Zh}$.-J. et al., 2021. Environmental drivers of Sphagnum growth in peatlands across the Holarctic region. Journal of Ecology 109 (1), 417-431. https://doi.org/10.1111/1365-2745.13499

Burenina, T.A., 2006. Izmenenie zapasov nadzemnoi fitomassy i emissii ugleroda pri pozharakh na lesobolotnykh kompleksakh o. Sakhalin [The dynamics of surface phytomass and carbon emission as affected by forest fires on the Sakhalin Island]. Vestnik Severo-Vostochnogo nauchnogo tsentra DVO RAN [Bulletin of the North-East Scientific Center of the Far East Branch of Russian Academy of Sciences] 2, 75-85. (In Russian).

Chumakov, L.S., 2013. Rastitel'nyi pokrov sosnyaka bagul'nikovogo na verkhovom bolote cherez 16 let posle lesnogo pozhara [Vegetable cover of the pine forest with Ledum palustre on the riding bog in 16 years after forest fire]. Ekologicheskiy vestnik [Ecological Bulletin] 2, 109-115. (In Russian).

Danilova, O.V., Belova, S.E., Kulichevskaya, I.S., Dedysh, S.N., 2015. Decline of activity and shifts in the methanotrophic community structure of an ombrotrophic peat bog after wildfire. Microbiology 84 (5), 624-629. http://doi.org/10.1134/ S0026261715050045

Denisenkov, V.P., 1980. Izmeneniye rastitel'nosti bolot Mologo-Sheksninskoi nizmennosti pod vozdeistviem khozyaistvennoi deyatel'nosti cheloveka [Change of vegetation of mires of the Mologa-Sheksna lowland under the influence of human economic activity]. In: Skarlygina-Ufimtseva, M.D. (ed.), Sovremennye problemy biogeografii [Modern Problems of Biogeography]. Leningrad State University, Leningrad, Russia, 69-78. (In Russian).

Doklad o sostoyanii i okhrane okruzhayushchei sredy Vologodskoi oblasti $v 2016$ godu [Report on the state and environmental protection of the Vologda Region in 2016], 2017. Department of Natural Re- 
sources and Environmental Protection of the Vologda Region, Vologda, Russia, 249 p. (In Russian).

Doklad o sostoyanii i okhrane okruzhayushchei sredy Vologodskoi oblasti $v 2009$ godu [Report on the state and environmental protection of the Vologda Region in 2009], 2010. Department of Natural Resources and Environmental Protection of the Vologda Region, Vologda, Russia, 235 p. (In Russian).

Doklad o sostoyanii i okhrane okruzhayushchei sredy Vologodskoi oblasti $v 2011$ godu [Report on the state and environmental protection of the Vologda Region in 2011], 2012. Department of Natural Resources and Environmental Protection of the Vologda Region, Vologda, Russia, 248 p. (In Russian).

Doklad o sostoyanii i okhrane okruzhayushchei sredy Vologodskoi oblasti $v 2014$ godu [Report on the state and environmental protection of the Vologda Region in 2014], 2015. Department of Natural Resources and Environmental Protection of the Vologda Region, Vologda, Russia, 249 p. (In Russian).

Efremova, T.T., Efremov, S.P., 1994. Torfyanye pozhary kak ekologicheskii faktor razvitiya lesobolotnykh ekosistem [Peat fires as an environmental factor in the development of forestwetland ecosystems]. Ekologiya [Ecology] 5, 27-34. (In Russian).

Efremova, T.T., Efremov, S.P., 2006. Pyrogenic transformation of organic matter in soils of forest bogs. Eurasian Soil Science 39 (12), 1297-1305. http:// doi.org/10.1134/S1064229306120039

Filonenko, I.V., Philippov, D.A., 2013. Otsenka ploshchadi bolot Vologodskoi oblasti [Estimation of the area of mires in the Vologda Region]. Trudy Instorfa [Proceedings of East European Institute of Peat] 7, 3-11. (In Russian).

Glukhova, T.V., Sirin, A.A., 2018. Losses of soil carbon upon a fire on a drained forested raised bog. Eurasian Soil Science 51 (5), 542-549. http://doi. org/10.1134/S1064229318050034

Golovatskaya, E.A., Porokhina, E.V., 2005. Botanika s osnovami fitotsenologii: Biologicheskaya produktivnost' bolotnykh biogeotsenozov. Uchebno-metodicheskoye posobie [Botany with the basics of phytocenology: Biological productivity of mire biogeocoenoses. Tutorial]. Tomsk State Pedagogical University, Tomsk, Russia, 64 p. (In Russian).

Grishutkin, O.G., 2012. Vliyanie pozharov 2010 goda na bolotnye ekosistemy Mordovskogo gosudarstvennogo prirodnogo zapovednika [The impact of the 2010 fires on the mire ecosystems of the
Mordovskii Nature Reserve]. Trudy Mordovskogo gosudarstvennogo prirodnogo zapovednika im. P.G. Smidovicha [Proceedings of the P.G. Smidovich Mordovia State Nature Reserve] 10, 261 265. (In Russian).

Grummo, D.G., Sozinov, O.V., Zelenkevich, N.A., Puchilo, A.V., Broska, T.V., 2010. Digressiya rastitel'nykh soobshchestv bolota pod vliyaniem pozharov razlichnoi stepeni intensivnosti [Digression of mire plant communities under the influence of fires of varying intensity]. Flora i rastitel'nost' respublikanskogo landshaftnogo zakaznika "Yel'nya" [Flora and vegetation of the Republican Landscape Reserve "Yelnya"]. Minsktipproekt, Minsk, Belarus, 97-119. (In Russian).

Hassel, K., Kyrkjeeide, M.O., Yousefi, N., Presto, T., Stenoien, H.K., Shaw, J.A., Flatberg, K.I., 2018. Sphagnum divinum (sp. nov.) and S. medium Limpr. and their relationship to $S$. magellanicum Brid. Journal of Bryology 40 (3), 197-222. https://doi.org/10.1 080/03736687.2018.1474424

Ignatov, M.S., Afonina, O.M., Ignatova, E.A., 2006. Check-list of mosses of East Europe and North Asia. Arctoa 15, 1-130. https://doi.org/10.15298/ arctoa.15.01

Khakimov, I.R., Sinyutkina, A.A., 2014. Kompleksnaya sistema otsenki pozharoopasnosti zabolochennykh territorii (na primere Shegarskogo raiona Tomskoi oblasti) [Complex system of the assessment of fire danger at wetlands (on the example of Shegarskiy Region in Tomsk Oblast)]. Izvestiya Samarskogo nauchnogo tsentra RAN [Proceedings of Samara Scientific Center of Russian Academy of Sciences] 16 (1-3), 688-691. (In Russian).

Kochubei, A.A., 2017. Ekologicheskie osobennosti vliyania pozharov na vozobnovlenie sosny (Pinus sylvestris L.) na verkhovykh bolotakh i sukhodolakh Zapadnoy Sibiri [Ecological features of the effect of fires on the regeneration of pine (Pinus sylvestris L.) in the raised bogs and drylands of theWestern Siberia]. Biological sciences PhD thesis abstract. Ekaterinburg, Russia, 24 p. (In Russian).

Kolesnikov, V.B., 2017. Vliyanie pozharov na sostav naseleniya pantsirnykh kleshchei sfagnovogo bolota $v$ lesostepi [Effect of fire on the fauna of oribatid mites of a Sphagnum mire in forest-steppe]. In: Prokin, A.A., Philippov, D.A. (eds.), Gidrobiologicheskie issledovanoya bolot [Hydrobiological studies of mires] (Trudy IBVV RAN [Transactions of IBIW RAS] 79/82), 82-87. (In Russian). http:// doi.org/10.24411/0320-3557-2017-10031 
Konstantinova, N.A., Bakalin, V.A., Andrejeva, E.N., Bezgodov, A.G., Borovichev, E.A., Dulin, M.V., Mamontov, Yu.S., 2009. Checklist of liverworts (Marchantiophyta) of Russia. Arctoa 18, 1-64. https://doi.org/10.15298/arctoa.18.01

Kopoteva, T.A., 1995. Ekzogennye suktsessii na bolotakh Priamur'ya [Demutation-degression successions in mires of Priamurye]. Botanicheskii Zhurnal [Botanical Journal] 80 (5), 68-73. (In Russian).

Kopoteva, T.A., Kuptsova, V.A., 2016. Effect of fires on the functioning of phytocoenoses of the peat bogs in the Middle-Amur Lowland. Russian Journal of Ecology 47 (1), 11-18. http://doi.org/10.1134/ S1067413615060089

Korchagin, A.A., 1954. Usloviya vozniknoveniya pozharov i gorimost' lesov evropeyskogo Severa [Fire conditions and forest burning in the European North]. In: Korchagin, A.A. (ed.), Ocherki po rastitel'nomu pokrovu SSSR. Sbornik 1 [Essays on the vegetation of the USSR. Vol. 1]. (Uchyonye zapiski LGU im. A.A. Zhdanova. № 166. Seriya geograficheskikh nauk. Vyp. 9 [Scientific Notes of A.A. Zhdanov Leningrad State University. No. 166. Series of Geographic Sciences. Is. 9]). Leningrad State University, Leningrad, Russia, 182-322. (In Russian).

Kosov, V.I., 2012. Torfyanye pozhary. Geoekologicheskie problemy, tekhnosfernaya bezopasnost' [Peat fires. Geoecological problems, technosphere safety]. St. Petersburg Polytechnic University, Saint Petersburg, Russia, 318 p. (In Russian).

Kučerová, A., Rektoris, L., Štechová, T., Bastl, M., 2008. Disturbances on a wooded raised bog - How windthrow, bark beetle and fire affect vegetation and soil water quality? Folia Geobotanica 43 (1), 49-67. https://doi.org/10.1007/s12224-008-9006-9

Kuhry, P., 1994. The role of fire in the development of Sphagnum-dominated peatlands in western boreal Canada. Journal of Ecology 82 (4), 899-910. https://doi.org/10.2307/2261453

Kurina, I.V., Klimova, N.V., 2016. Soobshchestva rakovinnykh ameb (Rhizopoda, Testaceafilosea, Testacealobosea) v bolotnykh mestoobitaniyakh posle vozdeistviya pozharov (yug Zapadnoi Sibiri) [Testate amoebae assemblages (Rhizopoda, Testaceafilosea, Testacealobosea) in bog habitats after effects of wild fires (south of the Western Siberia)]. Vestnik Tomskogo Gosudarstvennogo Universiteta. Biologiya [Tomsk State University Journal of Biology] 3, 161-181. (In Russian). http://doi. org/10.17223/19988591/35/10
Lebedeva, E.V., 2005. Issledovanie problemy torfyanykh pozharov $v$ Vologodskoi oblasti [Study of the problem of peat fires in the Vologda Region]. Materialy vserossiiskoi nauchnoi konferentsii studentov $i$ aspirantov "Molodyye issledovateli - regionam". T. 1 [Proceedings of the All-Russian Scientific Conference of Students and Postgraduates "Young Researchers for the Regions". Vol. 1]. Vologda, Russia, 31-32. (In Russian).

Lyapkina, A.A., 1985. Priroda i prirodnye resursy Prisukhonskoi niziny Vologodskoi oblasti: Uchebnoe posobie k spetskursu [Nature and natural resources of the Prisukhonskaya lowland of the Vologda Region: tutorial]. Vologda State Pedagogical Institute, Vologda, Russia, 85 p. (In Russian).

Makarenko, G.L., 2013. Umen'shenie pozharoopasnosti territorii cherez estestvennoye vozobnovlenie bolot [Reducing fire danger territories through natural recovery of swamps]. Sovremennye naukoemkie tekhnologii [Modern High Technologies] 11, 86-91. (In Russian).

Malaschuk, A.A., 2014. Postpirogennaya dinamika rastitel'nogo pokrova bolota Barskoe (Vologodskiy rayon) [Post-pyrogenic dynamics of the vegetation cover of the Barskoe mire (Vologda District)]. Materialy vserossiiskoi nauchnoi konferentsii studentov $i$ aspirantov "Molodyye issledovateli - regionam". T. 2 [Proceedings of the All-Russian Scientific Conference of Students and Postgraduates "Young Researchers for the Regions". Vol. 2]. Vologda, Russia, 94-96. (In Russian).

Mazing, V.V., 1960. Pozhary na verkhovykh bolotakh i smeny rastitel'nosti na bolotnykh garyakh [Fires in raised bogs and vegetation changes in mires cinders]. Uchenye zapiski Tartusskogo gosudarstvennogo universiteta [Tartu Riikliku Ülikooli toimetised] 93, 96-122. (In Russian).

Medvedeva, M.A., Vozbrannaya, A.E., Sirin, A.A., Maslov, A.A., 2019. Vozmozhnosti razlichnykh mul'tispektral'nykh kosmicheskikh dannykh dlya monitoringa neispol'zuemykh pozharoopasnykh torfyanikov i effektivnosti ikh obvodneniya [Potential of different multispectral satellite data for monitoring abandoned fire hazardous peatlands and rewetting effectiveness]. Sovremennyye problemy distantsionnogo zondirovaniya Zemli iz kosmosa [Modern problems of remote sensing of the Earth from space] 16 (2), 150-159. (In Russian). http:// doi.org/10.21046/2070-7401-2019-16-2-150-159

Minayeva, T.Yu., Sirin A.A., 2002. Torfyanyye pozhary - prichiny i puti predotvrashcheniya [Peat fires - causes and ways of prevention]. Nauka $i$ 
promyshlennost' Rossii [Science and industry of Russia] 9, 3-8. (In Russian).

Napreenko, M.G., 2002. Flora i rastitel'nost' verkhovykh bolot Kaliningradskoy oblasti [Flora and vegetation of raised bogs of Kaliningrad Region]. Biological sciences $P h D$ thesis. Kaliningrad, Russia, 291 p. (In Russian).

Novakovskiy, A.B., 2016. Vzaimodeystviye Excel i statisticheskogo paketa $R$ dlya obrabotki dannykh $v$ ekologii [Interaction between Excel and statistical package $\mathrm{R}$ for ecological data analysis]. Vestnik Instituta biologii Komi NC UrO RAN 3, 26-33. (In Russian). http://doi.org/10.31140/j.vestnikib.2016.3(197).4

Panov, V.V., Tsymlyakova, S.S., 2013. Prostranstvennaya struktura pozharov i gari na tekhnogenno narushennykh torfyanykh bolotakh [Spatial structure of fires and burnt areas in the technologically disturbed peat bogs]. Izvestiya RGO [The Russian Geographical Society Herald] 145 (1), 80-90. (In Russian).

Philippov, D.A., 2007. Antropogennye suktsessii bolotnykh ekosistem na vodosborakh taezhnoi zony Evropeiskogo Severa [Anthropogenic successions of mire ecosystems in the watersheds of the taiga zone of the European North]. In: Bolotova, N.L. (ed.), Antropogennye suktsessii vodosborov taezhnoy zony: bioindikatsiya i monitoring [Anthropogenic successions of watersheds of the taiga zone: bioindication and monitoring]. Vologda State Pedagogical University, Vologda, Russia, 56-64. (In Russian).

Philippov, D.A., 2010. Rastitel'nyi pokrov, pochvy i zhivotnyi mir Vologodskoi oblasti (retrospektivnyi bibliograficheskii ukazatel') [Plants, soils and animals of the Vologda Region (retrospective bibliographical index)]. Sad-Ogorod, Vologda, Russia, 217 p. (In Russian).

Philippov, D.A., 2015. Flora Shichengskogo vodno-bolotnogo ugod'ya (Vologodskaya oblast') [Flora of wetland "Shichengskoe" (Vologda Region, Russia)]. Fitoraznoobrazie Vostochnoy Evropy [Phytodiversity of Eastern Europe] 9 (4), 86-117. (In Russian). http://doi.org/10.24411/2072-88162015-10033

Philippov, D.A., Prokin, A.A., Przhiboro, A.A., 2017. Metody i metodiki gidrobiologicheskogo issledovaniya bolot: uchebnoe posobie [Methods and methodology of hydrobiological study of of mires: tutorial]. Tyumen State University, Tyumen, Russia, 207 p. (In Russian).
Popov, S.Yu., 2000. Pirogennye suktsessii sfagnofykh mkhov v Sredney Rossii [Afterfire successions of peat mosses in the Central Russia]. Botanicheskii Zhurnal 85 (2), 89-96. (In Russian).

Pyavchenko, N.I., 1955. Usloviya zabolachivaniya elovykh lesov i garei po nablyudeniyam $v$ Velikolukskoi i Vologodskoi oblastyakh [Conditions of swamping of spruce forests and fires according to observations in the Velikie Luki and Vologda regions]. Trudy Instituta Lesa AN SSSR [Proceedings of the Forest Institute of the Academy of Sciences of the USSR] 26, 17-61. (In Russian).

Rabotnov, T.A., 1978. O znachenii pirogennogo faktora dlya formirovaniya rastitel'nogo pokrova [On the importance of the firefactor for formation of vegetative cover]. Botanicheskii Zhurnal 63 (11), 1605-1611. (In Russian).

Sejbutis, A.A., 1961. K voprosu ob antropogennoi transformatsii bolotnykh urochishch landshaftov Litvy [To a question of anthropogenic transformation of mires landscapes in Lithuania]. Uchenyye zapiski Latviyskogo gosudarstvenogo universiteta [Valsts universitātes Zinātniskie raksti] 37 (4), 335358. (In Russian).

Semenova, K.S., 2016. Obosnovaniye protivopozharnogo shlyuzovaniya osushennykh torfyanikov v usloviyakh Meshcherskoy nizmennosti [The rationale for the fire locks of drained peatlands in the conditions of the Meshchera lowland]. Technical sciences PhD thesis abstract. Moscow, Russia, 24 p. (In Russian).

Shevelev, N.N., Komissarov, V.V., 1994. Prirodopol'zovanie i ekologicheskie problemy Vologodskoi oblasti [Nature management and environmental problems of the Vologda Region]. Rus', Vologda, Russia, 94 p. (In Russian).

Sirin, A.A., Makarov, D.A., Gummert, I., Maslov, A.A., Gul'be, Ya.I., 2019. Glubina progoraniya torfa i poteri ugleroda pri lesnom podzemnom pozhare [Depth of peat burning and carbon losses from an underground forest fire]. Lesovedenie [Russian Journal of Forest Science] 5, 410-422. (In Russian). http://doi.org/10.1134/S0024114819050097

Sirin, A., Medvedeva, M., Maslov, A., Vozbrannaya, A., 2018. Assessing the land and vegetation cover of abandoned fire hazardous and rewetted peatlands: comparing different multispectral Satellite data. Land 7 (2), 71. https://doi.org/10.3390/land7020071

Sirin, A., Minaeva, T., Vozbrannaya, A., Bartalev, S., 2011. Kak izbezhat' torfyanykh pozharov? [How to 
avoid peat fires?]. Nauka $v$ Rossii [Science in Russia] 2, 13-21. (In Russian).

Sretenskiy, V.A., 2004. Ekstrennoye tusheniye nizovykh lesnykh pozharov i torfyanikov bez vody [Emergency extinguishing of lower forest fires and peat bogs without water]. Perm State University, Perm, Russia, 188 p. (In Russian).

Torfyanoi Fond RSFSR. Vologodskaya oblast' [Peat cadastre of RSFSR. Vologda Region], 1955. Main Directorate of the Peat Fund under the Council of Ministers of the RSFSR, Moscow, Russia, XXIII + 652 p. (In Russian).

Tsibart, A.S., Gennadiev, A.N., Koshovskii, T.S., Gamova, N.S., 2016. Polycyclic aromatic hydrocarbons in pyrogenic soils of swampy landscapes of the Meshchera Lowland. Eurasian Soil Science 49 (3), 285-293. http://doi.org/10.1134/ S106422931603011X

Tzvelev, N.N., 2000. Opredelitel' sosudistykh rastenii Severo-Zapadnoi Rossii (Leningradskaya, Pskovskaya i Novgorodskaya oblasti) [Manual of the vascular plants of North-West Russia (Leningrad, Pskov and Novgorod provinces)]. St. Petersburg State Chemical-Pharmaceutical Academy Press, Saint Petersburg, 781 p. (In Russian).

Ul'baev, T.S., Bazayeva, M.G., 2012. Prirodnyi istochnik pozharov na bolote [Natural source of fires in the swamp]. Vestnik MGOU. Ser. Estestvennye nauki [Bulletin of the Moscow Region State University. Series: Natural Sciences] 1, 94-97. (In Russian).

Vomperskiy, S.E., Glukhova, T.V., Smagina, M.V., Kovalev, A.G., 2007. Usloviya i posledstviya pozharov $v$ sosnyakakh na osushennykh bolotakh
[The conditions and consequences of fires in pine forests on drained bogs]. Lesovedenie [Russian Journal of Forest Science] 6, 35-44. (In Russian).

Wein, R.W., MacLean, D.A. (eds.), 1983. The role of fire in northern circumpolar ecosystems. John Wiley \& Sons, New York, USA, 322 p.

Zaudalov, E.A., 2006. Issledovaniya samovozgoraniya i ekologicheskaya tsennost' torfa [Research on spontaneous combustion and the ecological value of peat]. Materialy vserossiiskoi nauchnoi konferentsii studentov $i$ aspirantov "Molodyye issledovateli - regionam". T. 1 [Proceedings of the All-Russian Scientific Conference of Students and Postgraduates "Young Researchers for the Regions". Vol. 1]. Vologda, Russia, 263-265. (In Russian).

Zaydelman F.R., 2014. Zashchita torfyanykh pochv ot degradatsii i unichtozheniya pri pozharakh [Protection of peat soils from degradation and destruction in fires]. Melioratsiya $i$ vodnoye khozyaystvo [Melioration and Water Management] 1, 36-39. (In Russian).

Zaydelman, F.R., Shvarov, A.P., 2002. Pirogennaya i gidrotermicheskaya degradatsiya torfyanykh pochv, ikh agroekologiya, peschanye kul'tury zemledeliya, rekul'tivatsiya [Pyrogenic and hydrothermal degradation of peat soils, their agroecology, sandy crops, reclamation]. Moscow State University, Moscow, Russia, 165 p. (In Russian).

Zhukov, I.V., Potapov, A.I., 2010. Minimizatsiya posledstvii torfyanykh vozgoranii [Minimization of consequences of peat inflammations]. Ekologia i promyshlennost Rossii [Ecology and Industry of Russia] 7, 31-33. (In Russian). 